\title{
Immunotherapy - 2072. Therapeutic effect and higher safety profile for allergic asthma in Cuban patients with sublingual immunmotherapy using tropical domestic mite allergen vaccines
}

\author{
Raúl Lázaro Castro Almarales 1*, Mirta Alvarez Castello², Mercedes Ronquillo Díaz ${ }^{3}$, Mayda Gonz\&\#225lez León ${ }^{4}$, \\ Alexis Labrada Rosado ${ }^{5}$, José S Rodr\&\#237guez Canosa ${ }^{6}$, Bárbara Ivonne Navarro Viltres ${ }^{4}$, Yunia Olivia Diaz ${ }^{7}$ ' \\ Maytee Mateo Morejón ${ }^{8}$
}

From 2nd WAO International Scientific Conference (WISC 2012)

Hyderabad, India. 6-9 December 2012

\section{Background}

Subcutaneous allergen-specific immunotherapy is burdened with the risk of severe systemic reactions; therefore, sublingual administration route has been increasingly investigated worldwide. The goal was to assess the therapeutic effect and safety of allergen therapeutic vaccines of Dermatophagoides pteronyssinus, Dermatophagoides sibo$n e y$ and Blomia tropicalis House-Dust mites (VALERGEN, BIOCEN, Cuba) by sublingual route, in asthmatic patients.

\section{Methods}

Three Double-Blind Placebo-Controlled clinical trials were performed in 40 patients each, showing asthmatic symptoms and positive predominant Skin Prick Test (SPT) to each mite, respectively. Half of subjects were randomized to placebo. Patients received the treatment consisting on sublingual drops with increasing daily doses for 3 weeks and maintenance doses (2000 BU) twice a week until 12 moths. Therapeutic effect was assessed after 6 and 12 months using symptoms/medication diary cards, peak expiratory flow (PEF) measures and skin sensitivity to investigated mites. Adverse reactions were classified using the World Allergy Organization scale.

'Allergens Department, National Center of Bioproducts (BIOCEN), Allergology and General Integral Medicine, La Habana, Cuba

Full list of author information is available at the end of the article

\section{Results}

The treatment reduced significantly $(\mathrm{p}<0.01)$ clinical symptoms (38\%, CI95\%: 33-44) and medication intake (26\%, CI95\%:21-32) with respect to placebo. The skin sensitivity to the allergens decreased also significantly $(p<0.01)$. The allergen amount needed to induce a positive SPT increased 52 -fold. PEF variability decreased also significantly $(\mathrm{p}<0.05)$. The treatment was considered effective in $77 \%$ of patients. A major advantage as compared to subcutaneous route was a remarked lower frequency of adverse effects. Local reactions were noted only in $0.43 \%$ of administrations. No systemic reactions were observed.

\section{Conclusions}

Summarizing sublingual immunotherapy using VALERGEN vaccines is effective and safe in mite-sensitive asthmatic patients.

\footnotetext{
Author details

${ }^{1}$ Allergens Department, National Center of Bioproducts (BIOCEN), Allergology and General Integral Medicine, La Habana, Cuba. ${ }^{2}$ Allergology Department, University Hospital General Calixto García, Havana, Cuba; WAO Member; Cuban Society of Allergy, Asthma and Clinical Immunology, Member; Cuban Society of Immunology Member. ${ }^{3}$ Allergen Service, University Hospital "General Calixto García", Cuba. "Docent Polyclinic "Pedro Fonseca", Havana, Cuba; Cuban Society of Integral General Medicine, Member; Cuban Society of Allergy, Asthma and Clinical Immunology, Member; Cuban Society of Immunology Member. ${ }^{5}$ Cuban Society of Allergy, Asthma and Clinical Immunology, Mayabeque, Cuba. ${ }^{6}$ Allergen Service, University Hospital General Calixto García, Havana, Cuba; WAO Member; Cuban Society of
} 
Allergy, Asthma and Clinical Immunology, Member; Cuban Society of Immunology Member. ${ }^{7}$ Allergen Department, National Center of Bioproducts (BIOCEN), Mayabeque, Cuba; Cuban Society of Immunology, Member; Cuban Society of Allergy, Asthma and Clinical Immunology, Member. ${ }^{8}$ Allergen,

Biocen, Cuba.

Published: 23 April 2013

doi:10.1186/1939-4551-6-S1-P154

Cite this article as: Almarales et al:: Immunotherapy - 2072.

Therapeutic effect and higher safety profile for allergic asthma

in Cuban patients with sublingual immunmotherapy using tropical

domestic mite allergen vaccines. World Allergy Organization Journal

2013 6(Suppl 1):P154.

Submit your next manuscript to BioMed Central and take full advantage of:

- Convenient online submission

- Thorough peer review

- No space constraints or color figure charges

- Immediate publication on acceptance

- Inclusion in PubMed, CAS, Scopus and Google Scholar

- Research which is freely available for redistribution

Submit your manuscript at www.biomedcentral.com/submit 